\title{
Maja Laklija,
}

University of Zagreb, Department of Social Work, Faculty of Law

\section{Vladimir Ilievski,}

Ss. Cyril and Methodius University in Skopje

Faculty of Philosophy - Skopje Institute of Social Work and Social Policy

"Mother Theresa"

\section{COMPARATIVE ANALYZE OF FOSTER CARE FOR ADULTS IN REPUBLIC OF CROATIA AND REPUBLIC OF MACEDONIA}

UDK:364-783-053.9(497.7)

\begin{abstract}
:
The aim of this work is to show practice and opportunities for improvement of foster care for adults in Republic of Croatia and Republic of Macedonia, through a comparative analysis of the legal framework governing foster care. The analysis will focus on the comparison of certain statutory provisions that are related to foster care and state the main differences that exist in these countries. We will analyze the provisions relating to the types of foster care present in those countries, the accommodation capacities, the conditions to be met to perform foster activities, training and education of foster careers, the issuance of a license to conduct foster care and issues related with conclusion of the contract and compensation for foster carers. We will also display statistics about the current situation on the field of foster care in each country and propose guidelines for the further development of foster care for adults in Croatia and Macedonia.
\end{abstract}

Key words: foster care, adults, legislative framework, guidelines 


\section{Statistical data of adult persons placed in foster families}

Data processing was performed on the annual statistical reports prepared by the Ministry of Social Policy and Youth of Croatia and on data received from the Institute of Social Activities from Macedonia (Table 1. and Table 2.).

Table 1 Number of foster families in the period 2004-2013

\begin{tabular}{|l|l|l|l|l|l|l|l|l|l|l|}
\hline $\begin{array}{l}\text { Number of } \\
\text { foster } \\
\text { families for } \\
\text { adults and } \\
\text { elderly: }\end{array}$ & $\mathbf{2 0 0 4}$ & $\mathbf{2 0 0 5}$ & $\mathbf{2 0 0 6}$ & $\mathbf{2 0 0 7}$ & $\mathbf{2 0 0 8}$ & $\mathbf{2 0 0 9}$ & $\mathbf{2 0 1 0}$ & $\mathbf{2 0 1 1}$ & $\mathbf{2 0 1 2}$ & $\mathbf{2 0 1 3}$ \\
\hline $\begin{array}{l}\text { - in } \\
\text { Republic of } \\
\text { Macedonia }\end{array}$ & 48 & 58 & 70 & 82 & 95 & 103 & 146 & 152 & 170 & 180 \\
\hline $\begin{array}{l}\text { - in } \\
\text { Republic of } \\
\text { Croatia }\end{array}$ & 1355 & 1339 & 1338 & 1241 & 1267 & 1303 & 1381 & 1409 & 1438 & 1533 \\
\hline
\end{tabular}

The insight in the statistical reports by the Croatian Ministry of Social Policy and Youth indicates that the total number of foster families remained more or less constant in the period 2004-2013 with a slight growth trend. Similar is with the number of adults and older persons placed in foster families in the same period.

According to the statistics from the Institute of Social Activities may be noticed increase in the number of foster families in Republic of Macedonia, regarding the comparison made with the number of foster families from 2004 to 2013. So that the total number of foster families in 2004 was 48 foster families, and in 2013 was 180 foster families. 
Marija Laklija, Vladimir Ilievski: Comparative analyze of foster care for adults in...

Table 2 Number of adults and older persons placed in foster families in the period 2004-2013

\begin{tabular}{|c|c|c|c|c|c|c|c|c|c|c|}
\hline $\begin{array}{c}\text { Number of } \\
\text { users: }\end{array}$ & $\mathbf{2 0 0 4}$ & $\mathbf{2 0 0 5}$ & $\mathbf{2 0 0 6}$ & $\mathbf{2 0 0 7}$ & $\mathbf{2 0 0 8}$ & $\mathbf{2 0 0 9}$ & $\mathbf{2 0 1 0}$ & $\mathbf{2 0 1 1}$ & $\mathbf{2 0 1 2}$ & $\mathbf{2 0 1 3}$ \\
\hline $\begin{array}{c}- \text { in } \\
\text { Republic of } \\
\text { Macedonia }\end{array}$ & 1 & 1 & 2 & 4 & 1 & 6 & 9 & 10 & 15 & 16 \\
\hline $\begin{array}{c}- \text { in } \\
\text { Republic of } \\
\text { Croatia }\end{array}$ & 3457 & 3628 & 3724 & 3439 & 3213 & 3150 & 3263 & 3537 & 3819 & 3775 \\
\hline
\end{tabular}

As indicated in Table 2, the number of adult and senior users placed in foster families slightly increased in the period of 2003-2006, while the year 2007 was marked with a trend of decrease. This can be explained by the introduction of the new Foster Care Act in 2007, which lays down stricter rules in comparison to the legislation previously in force.

Table 3 Number of foster caregivers and adults and older persons placed in foster families in the period 2008-2013 in Croatia

\begin{tabular}{|l|l|l|l|l|l|l|}
\hline & $\mathbf{2 0 0 8}$ & $\mathbf{2 0 0 9}$ & $\mathbf{2 0 1 0}$ & $\mathbf{2 0 1 1}$ & $\mathbf{2 0 1 2}$ & $\mathbf{2 0 1 3}$ \\
\hline 1 user & 512 & 490 & 497 & 459 & 296 & 434 \\
\hline 2 users & 116 & 164 & 189 & 206 & 189 & 251 \\
\hline 3 users & 142 & 156 & 179 & 165 & 178 & 189 \\
\hline 4 users & 367 & 384 & 415 & 415 & 509 & 577 \\
\hline More than 4 & 91 & 50 & 38 & 35 & 31 & 44 \\
\hline
\end{tabular}

As shown in the Table, most of foster caregivers provide homes for one or four users (Table 3). During the two-year period there were no other significant differences apart from the increased number of foster families with two or more users and decreased number of foster families with four users which started to increase in $2013^{\text {th }}$. This data implies a trend of use of unused accommodation resource. 
Table 4 Number of adult and older persons placed in foster families under user categories in the period 2004-2013 in Croatia

\begin{tabular}{|l|l|l|l|l|l|l|l|l|l|l|}
\hline & $\mathbf{2 0 0 4}$ & $\mathbf{2 0 0 5}$ & $\mathbf{2 0 0 6}$ & $\mathbf{2 0 0 7}$ & $\mathbf{2 0 0 8}$ & $\mathbf{2 0 0 9}$ & $\mathbf{2 0 1 0}$ & $\mathbf{2 0 1 1}$ & $\mathbf{2 0 1 2}$ & $\mathbf{2 0 1 3}$ \\
\hline $\begin{array}{l}\text { Older persons } \\
(65+)\end{array}$ & 1826 & 1917 & 1902 & 1877 & 1672 & 1752 & 1763 & 1716 & 1951 & 2171 \\
\hline $\begin{array}{l}\text { Physically or } \\
\text { mentally disabled } \\
\text { persons }\end{array}$ & 746 & 759 & 790 & 607 & 610 & 668 & 683 & 704 & 662 & 636 \\
\hline $\begin{array}{l}\text { Persons with } \\
\text { mental health } \\
\text { problems, persons } \\
\text { addicted to } \\
\text { alcohol/drugs/other } \\
\text { substances }\end{array}$ & 883 & 933 & 957 & 948 & 909 & 726 & 812 & 927 & 939 & 952 \\
\hline $\begin{array}{l}\text { Adults - victims of } \\
\text { family violence }\end{array}$ & 4 & 5 & 3 & 4 & 1 & 1 & 3 & 20 & 13 & 16 \\
\hline $\begin{array}{l}\text { Pregnant women 3 } \\
\text { months prior to } \\
\text { giving birth or } \\
\text { parents with a } \\
\text { child up to 6 } \\
\text { months of age }\end{array}$ & 3 & 0 & 0 & 3 & 3 & 3 & 2 & 0 & 6 & 0 \\
\hline
\end{tabular}

The number of adult and older persons placed in foster families under the above categories and for the period 2003-2013 indicates that most of users placed in foster families belong to the category of persons older than (65+), followed by adult persons with mental health problems and addicts and disabled persons. Only a small number of people found their foster homes after experiencing family violence, during pregnancy or with a child up to 6 months of age. 
Table 5 Number of adult persons placed in foster families under user categories in the period 2004-2013 in Macedonia

\begin{tabular}{|l|l|l|l|l|l|l|l|l|l|l|}
\hline & 2004 & 2005 & 2006 & 2007 & 2008 & 2009 & 2010 & 2011 & 2012 & 2013 \\
\hline $\begin{array}{l}\text { Physically or } \\
\text { mentally disabled } \\
\text { persons }\end{array}$ & 1 & 1 & 1 & 3 & 5 & 5 & 8 & 9 & 13 & 14 \\
\hline $\begin{array}{l}\text { Bearer of foster } \\
\text { family }\end{array}$ & & & 1 & 1 & 1 & 1 & 1 & 1 & 1 & 1 \\
\hline $\begin{array}{l}\text { Children without } \\
\text { parental care } \\
\text { (until 26 year) }\end{array}$ & & & & & & & & & 1 & 1 \\
\hline
\end{tabular}

As shown in the Table 5, In terms of the number of adults who are accommodated in foster families, dominate people with mental and physical disabilities and most of them previously have been accommodated in foster families as children, which can remain in foster care until they turn age of 26 years, persons that have the status of children without parental care, which may be placed in foster care until they turn age of 26 years.

Table 6.Types of the non-institutional care for older and disabled persons in Republic of Macedonia and Croatia

\begin{tabular}{|l|l|l|}
\hline & Republic of Macedonia & Republic of Croatia \\
\hline $\begin{array}{l}\text { Types of the } \\
\text { non- } \\
\text { institutional } \\
\text { care for older } \\
\text { and disabled } \\
\text { persons }\end{array}$ & $\begin{array}{l}\text { - day care centers for older and } \\
\text { disabled persons, }\end{array}$ & $\begin{array}{l}\text { - day care centers operating within } \\
\text { specialized homes for older and } \\
\text { disabled persons, } \\
\end{array}$ \\
$\begin{array}{l}\text { living with support in the } \\
\text { community } \\
\text {-non-governmental organizations } \\
\text { that focus their main activities on } \\
\text { providing home assistance }\end{array}$ & $\begin{array}{l}\text { - gerontological centers } \\
\text { - non-governmental organizations } \\
\text { that focus their main activities on } \\
\text { providing home assistance }\end{array}$ \\
\hline
\end{tabular}

Foster care is nowadays recognized as a more humane, natural and often more affordable and available type of care for adults and older persons in comparison with the institutional forms of care (Laklija and Barišec, 2012.). There are different types of the non-institutional care for older and disabled persons in Republic of Croatia: day care centers 
operating within specialized homes for older and disabled persons, gerontological centers. Recently, we have witnesses an increasing number of non-governmental organizations that focus their main activities on providing home assistance to older persons, including social care services. Also, there are forms of non-institutional care for adult persons as a direct result of the recently introduced institute of the adult foster care. Until 2007, when the first Foster Care Act came into force, foster care was regulated by the Social Care Act (OG, no. 73/97) and related by-laws contained in several ordinances and decisions. The Foster Care Act stipulates different categories of users for the placement in foster families: a) children and youth, and b) adult and older persons. Adults and older persons for placement in foster families fall under the following categories: persons with physically and intellectual disabilities, adult mental patients, persons addicted to alcohol, drugs or other substances; older persons (65+); adult victims of family violence, and pregnant women 3 months prior to giving birth or a parent with a child younger than 6 months of age. As opposed to child foster care; there are no studies and official indicators related to the development of adult and older person foster care.

Table7. Categories of adults and older persons placed in foster families in Republic of Macedonia and Croatia

\begin{tabular}{|c|c|c|}
\hline & Republic of Macedonia & Republic of Croatia \\
\hline $\begin{array}{l}\text { Categories of } \\
\text { adults and } \\
\text { older persons } \\
\text { placed in } \\
\text { foster } \\
\text { families }\end{array}$ & $\begin{array}{l}\text { - Elderly person, } \\
\text { - adult with disabilities and } \\
\text { persons with intellectual } \\
\text { disabilities who is unable to care } \\
\text { for them and due to housing and } \\
\text { family situation, it is not able to } \\
\text { provide care otherwise } \\
\text { - A person with moderate severe } \\
\text { disabilities, } \\
\text { - a person with profound } \\
\text { intellectual disabilities and } \\
\text { persons with permanent physical } \\
\text { disability who needs permanent } \\
\text { care and nursing. }\end{array}$ & $\begin{array}{l}\text { - older persons }(65+) \text {; } \\
\text { - persons with physically and } \\
\text { intellectual disabilities, } \\
\text { - adult with mental health illness, } \\
\text { persons addicted to alcohol, drugs } \\
\text { or other substances; } \\
\text { - adult victims of family violence, } \\
\text { and } \\
\text { - pregnant women } 3 \text { months prior } \\
\text { to giving birth or a } \\
\text { - parent with a child younger than } 6 \\
\text { months of age }\end{array}$ \\
\hline
\end{tabular}


Developing the process of deinstitutionalization in the system of social protection and enforcement non-institutional forms of social protection is imperative for the Republic of Macedonia in the process of implementing the reforms and strengthening the social protection system.According to the Law on Social Protection of the Republic of Macedonia (2014), article 26, non-institutional protection that is realized at and through the Center for social work includes: first social service for the social protection beneficiaries, assistance to individual, assistance to family, home care and assistance to individuals and family, daily and temporary assistance for individual and family, accommodation in foster family, accommodation in small group home and organized life support.

\section{Foster care for adults and older persons pursuant to the Foster}

\section{Care Act}

Pursuant to the Croatian Foster Care Act (OG no. 90/11) foster care for adults is a type of care outside of a person's family where adults have the right to basic living needs which cannot be satisfied by their own families and which they cannot satisfy on their own. A foster family is defined as a family that has the permission to provide foster care and it is composed of a foster caregiver, his or her spouse or partner and other relatives living in the same household. In order to place adults, older and disabled persons in foster families, foster caregivers need to meet certain legal requirements such as age (21 to 60 years of age, except in case of a congenial family); Croatian citizenship and residence in the Republic of Croatia; mental and physical health and capabilities required for the protection, assistance, care, education and satisfaction of service users' needs. The Law emphasizes diverse social and placement preconditions. The Law also stipulates that a single foster family shall accommodate a maximum of four service users or two in case of a one person household. A foster caregiver has the right to a monthly remuneration for the user's needs as well as an additional supplement for the care and efforts resulting from everyday assistance provided to a service user. The amount of that benefit depends on the user's age, health condition and specific needs and it is determined by the minister responsible for social care. 
Table 8. Obligations of foster caregivers in Republic of Macedonia and Croatia

\begin{tabular}{|c|c|c|}
\hline & Republic of Macedonia & Republic of Croatia \\
\hline $\begin{array}{l}\text { Foster } \\
\text { caregivers } \\
\text { are obliged } \\
\text { to: }\end{array}$ & $\begin{array}{l}\text { - Implementing individual } \\
\text { treatment plan for the beneficiary } \\
\text { in the foster family; } \\
\text { - To comply with the obligations } \\
\text { of the foster family involved in } \\
\text { the contract with the Centre for } \\
\text { Social Work; } \\
\text { - Provide proper care, health } \\
\text { care, food, clothing, shoes, } \\
\text { recreational and cultural } \\
\text { activities, } \\
\text {-To provide assistance to service } \\
\text { users in the satisfaction of their } \\
\text { everyday needs; } \\
\text { - To provide regular contact with } \\
\text { the parent or other close relatives } \\
\text { of person who is placed in a } \\
\text { foster family; } \\
\text { - At least to inform the Centre for } \\
\text { Social Work for the state and } \\
\text { changes at the beneficiary who is } \\
\text { admitted at the foster family; } \\
\text { - The foster family should report } \\
\text { to the Centre for Social Work at } \\
\text { least once a year and depending } \\
\text { on the needs and even more times } \\
\text { and } \\
\text { - In coordination with the Center } \\
\text { for Social Work to take certain } \\
\text { measures and activities that are in } \\
\text { the interest of meeting the needs } \\
\text { of the person who is resident at } \\
\text { foster family. }\end{array}$ & $\begin{array}{l}\text { - to perform personal preparations as } \\
\text { well as preparations of other family } \\
\text { members needed prior to the } \\
\text { placement of service users; } \\
\text { - to participate in the development of } \\
\text { individual plans for the placement of } \\
\text { service users; } \\
\text { - undertake activities for the } \\
\text { adjustment of service users to their } \\
\text { new families and environment; } \\
\text {-provide proper care, food, clothing } \\
\text { and shoes; } \\
\text { - undertake activities related to the } \\
\text { protection and improvement of users' } \\
\text { health condition; } \\
\text { - prepare users for entering foster } \\
\text { families and abide by the } \\
\text { instructions given by the competent } \\
\text { non-institutional that issued the } \\
\text { decision to provide foster care; } \\
\text { - to provide assistance to service } \\
\text { users in the satisfaction of their } \\
\text { everyday needs; } \\
\text { - to foster the acquisition of } \\
\text { particular skills directly linked to } \\
\text { users' capabilities in order to make } \\
\text { them independent; } \\
\text { - to support service users' } \\
\text { professional activities harmonized } \\
\text { with their mental and physical } \\
\text { capabilities and interests, } \\
\text { - to stimulate recreational and } \\
\text { cultural activities and } \\
\text { - to include adults in the life of local } \\
\text { communities in accordance with } \\
\text { theeds and capabilities. }\end{array}$ \\
\hline
\end{tabular}


In Croatia person who wishes to provide foster care to an older or disabled person needs to obtain the relevant license from a social services center (Article 10: Foster Care Act). The foster care team operating within the Social Services Centers issues the permit based on their findings and evaluates whether all the conditions have been met and issu the permit for the period of 3 years. Upon the expiration of that period, the decision can be renewed. The competent Social Services Center is also obliged to perform education and training of the foster family (at least 20 hours of lectures, workshops and group and practical activities) prior to the foster placement (Ordinance on the content and duration of education and training of foster families, OG no. 48/08). The objective of such training is to educate potential foster caregivers about the content, purpose and ways to perform foster care, rights and obligations of foster caregivers, users' needs, etc. The education also includes particular skills needed for providing care to older persons, i.e. positioning and turning over older persons in their beds, providing users with the optimal nutrition and hygiene, medical treatments and medication, organization of free time and similar. The Regulation on housing, social and other conditions for performing foster care (OG no. 48/08) stipulates that housing must consist of the required number of functional facilities depending on the number of family members and the type and number of users and that it must be owned, co-owned or rented by the foster caregiver or a member of the foster family.

In Republic of Macedonia the form of fostering traditionally is applied for more than 30 years. Solid legal framework and previous positive experiences with foster care families are increasingly arising from the need to promote and develop the foster care family as a form of protection for the children and adults. Foster family provides accommodation for people in general, specialized, intervention and temporary accommodation. The foster family provides accommodation and care for people, care and personal hygiene, nutrition and health care, education, necessary clothing, footwear, provides regular contact with the parent or other close relatives of person who is placed in a foster family. Under the legislation, the Center for Social Work in foster family can accommodate up to five people, two people with moderate and severe disabilities, person with the most severe disabilities, and two people with 
permanent physical disabilities. The foster family receives financial assistance for placed child as compensation for the care. According to existing national legislation Ministry of Labor and Social Policy (MLSP)directs its activities towards increasing the number of foster families, in promoting this form of social protection of citizens and increasing financial assistance for carers. The novelty is the implementation of PRIDE international program that can improve the quality of care for children within the foster care families. The program involves providing competencies, professional training and strengthening of all involved in the system of support for foster families. Center for Social Work as social institution monitors and coordinates the activities linked to the housing and care of the person in foster care.

\section{Conclusion}

The aging of population thus becomes one of the most important elements of social development increasingly imposing new demands to society. The non-institutional care in the Republic of Croatia and Macedonia presently holds an increasingly important place in social care for adults with a very clear final goal: to improve the quality of services for persons in need of the social protection. Although this form of noninstitutional protection is less common in the care of adults, it is increasingly emerging the need to be applied and to include larger number of people who are in social risk. The both countries provides the care and protection through the system of institutional care, but also by developing non- institutional forms of care such as foster families. Deinstitutionalization is a long term process and this model of care involves a series of supplementary elements such as better cooperation between the public and civil sector in the field of providing care outside of a person's family, public institutions reform aiming to improve the quality of services through the development of professional services and support to local communities. In both countries there is an apparent lack of studies on the topic of adult and older person foster care and its various aspects. To conclude, in Republic of Croatia and Macedonia it is necessary in the future to develop and encourage this form of the non-institutional by 
Marija Laklija, Vladimir Ilievski: Comparative analyze of foster care for adults in...

promoting this form of care for adults people determined by the legal frame and social protection of people placed in foster families and their caregivers, strengthening their capacity and the ability to cover other socially vulnerable individuals, as are covered persons under social risk. 


\section{Literature}

Laklija, M. i Barišec, A. (2014.) The experience of foster care for adult persons with mental disorders from the perspective of foster caregiver. Social Psychiatry, 42 (1), 50-61

Law on Social Protection, Republic of Macedonia (OG no. 116/14)

Law on Family, Republic of Macedonia (OG no. 153/14)

Ludwig Boltzmann Institute of Human Rights (BIM-FV)- Skopje \&MLSP: Decentralization of social protection in the Republic of Macedonia factual situation, challenges and opportunities at the local level, MLSP, BIM-FB Skopje, 2002

Study on poverty and social exclusion in the Republic of Macedonia: Local social problems and needs, (BIM-FV)- Skopje \&MPPS, Skopje, 2011

Ministry of Health and Sociale Care (2010). National plan for deinstitutionalization and transformation of social care homes and other legal entities engaged in social welfare in Croatia2011. - 2016. (2018.).Zagreb: Ministry of Health and Sociale Care.

Ministry of Health and Sociale Care (2003-2009). The statistical reports 20032009. Zagreb: Ministry of Health and Sociale Care .

National strategy for the social security system of the Republic of Macedonia (2008-2012), the Ministry of Labor and Social Policy, Ministry of Labour and Social policy, 2008

The Family Act (OG no. 116/03, 17/04, 136/04, 107/07).

The Constitution (OG no. 55/01).

The Social Care Act (OG no. 73/97, 27/01, 59/01, 82/01, 103/03, 44/06, 79/07, 33/12).

The Foster Care Act (OG no. 79/07, 90/11).

The Foster Care Act, Republic of Macedonia (OG no.15/13)

Žganec, N., Rusac, S. and Laklija, M. (2008). Trends in the Care for the Elderly in the Republic of Croatia and the EU Member States. Croatian Journal of Social Policy, 15 (2), 171-188. 